JURNAL
PENELITIAN PENDIDIKAN IPA $\begin{gathered}\begin{array}{c}\text { e-ISSN : 2407-795X } \\ \text { p-ISSN : 2460-2582 }\end{array} \\ \begin{array}{c}\text { Vol 2, No, 2 } \\ \text { Juli } 2016\end{array} \\ \text { http://jurnal.unram.ac.id/index.php/jpp-ipa }\end{gathered}$

\title{
PENERAPAN PEMBELAJARAN INVESTIGASI KELOMPOK UNTUK MENINGKATKAN KETERAMPILAN PROSES SAINS DITINJAU DARI INTELLIGENCE QUOTIENT SISWA
}

\author{
Raudatus Solihah ${ }^{1}$, Agus Abhi Purwoko ${ }^{2}$, Erin Ryantin Gunawan ${ }^{2}$ \\ Program Studi Magister Pendidikan IPA Program Pascasarjana Universitas Mataram ${ }^{123}$ \\ Email: celesta_golve@yahoo.com
}

\begin{tabular}{|c|c|}
\hline Key Words & Abstract \\
\hline $\begin{array}{l}\text { Group } \\
\text { investigation } \\
\text {, science } \\
\text { process skill, } \\
\text { intelligence } \\
\text { Quotient } \\
\text { (IQ)ABSTRA } \\
\text { CT }\end{array}$ & $\begin{array}{l}\text { This research aims to know the effect of group investigation learning on student's } \\
\text { science process skill based on their IQ in SMAN } 1 \text { Mataram for eleventh grade students. } \\
\text { This is a quasi experimental study using pretest postest control group design design. } \\
\text { Pretest was taken to get data of student's IQ. Posttest was also conducted to measure } \\
\text { student's science process skill. Sample was taken using nonprobability sampling from } \\
\text { the population of eleventh grade student in SMAN } 1 \text { Mataram.The sample was two } \\
\text { group of student each from two class, class XI sains } 6 \text { and as experimental group and } \\
\text { class XI sains } 5 \text { as control group. The average os Student's IQ on experimental group } \\
\text { and control group were equal, both at } 112 \text {. Learning processes were } 12 x 45 \text { minutes } \\
\text { long in total. The experimental group showed better average score on posttest where } \\
\text { they scored } 82.40 \text { on average, while control group only scored } 74.83 \text { on average. This } \\
\text { value is statistically significant, at p }=0.007 \text {, less that } 0.005 \text {. This result shows that } \\
\text { implementation of group investigation can increase student's science process skill. }\end{array}$ \\
\hline Kata Kunci & Abstrak \\
\hline $\begin{array}{l}\text { Investigasi } \\
\text { Kelompok, } \\
\text { Keterampila } \\
\mathrm{n} \quad \text { proses } \\
\text { sains, } \\
\text { Intelligence } \\
\text { Quatient } \\
\text { (IQ) }\end{array}$ & $\begin{array}{l}\text { Penelitian ini bertujuan untuk mengetahui pengaruh model pembelajaran Investigasi } \\
\text { Kelompok terhadap keterampilan proses sains ditinjau dari Intelligence Quatient (IQ) } \\
\text { siswa kelas XI SMA Negeri } 1 \text { Mataram. Rancangan metode penelitian yang digunakan } \\
\text { yaitu eksperimen semu menggunakan desain penelitian pre-test pos-test nonequivalent } \\
\text { control group design. Pre-test yang digunakan dalam penelitian ini adalah proxy-test } \\
\text { Intelligence Quatient (IQ) yang telah di uji oleh ahli psikologi. Sedangkan untuk post-test } \\
\text { menggunakan soal uraian untuk mengukur keterampilan proses sains. Sampel penelitian } \\
\text { adalah siswa kelas XI Sains } 6 \text { sebagai kelas eksperimen dan kelas XI Sains } 5 \text { sebagai } \\
\text { kelas kontrol. Pengambilan sampel dilakukan dengan teknik sampel nonprobabilitas. } \\
\text { Nilai rata-rata Intelligence Quatient (IQ) pada kelas eksperimen adalah } 112 \text { sedangkan } \\
\text { pada kelas kontrol sebesar } 112 \text {. Proses pembelajaran dilakukan selama } 12 \mathrm{x} 45 \text { menit. } \\
\text { Rata-rata nilai post-test untuk kelas eksperimen } 82,40 \text { sedangkan untuk kelas kontrol } \\
\text { memiliki nilai rata-rata } 74,83 \text {. Hasil penelitian signifikan (p) sebesar } 0,007 \text { lebih kecil } \\
\text { dari 0,05 menunjukkan bahwa penerapan pembelajaran investigasi kelompok dapat } \\
\text { meningkatkan keterampilan proses sains. }\end{array}$ \\
\hline
\end{tabular}




\section{PENDAHULUAN}

Pendidikan Nasional bertujuan untuk mengembangkan potensi peserta didik agar menjadi manusia yang beriman dan bertakwa kepada Tuhan Yang Maha Esa, berakhlak mulia, sehat, berilmu, cakap,kreatif,mandiri dan menjadi warga negara yang berdemokratis serta bertanggung jawab. Untuk itu kualitas pendidikan yang dimiliki tidaklah cukup diukur hanya dengan tuntasnya peserta didik dalam menjawab soal-soal ulangan saja. Tetapi lebih dari pada itu yakni dituntut pada proses yang harus mereka lakukan untuk menemukan konsep konsep yang akan mereka pergunakan dalam memecahkan permasalahan.

Fakta teoritis menyatakan telah banyak usaha yang dapat dilakukan untuk memperbaiki kualitas pendidikan diantaranya pembaharuan kurikulum, proses belajar mengajar, peningkatan kualitas guru, pengadaan buku pelajaran,sarana belajar mengajar, penyempurnaan sistem penilaian dan sebagainya. Pada materi Hidrolisis Garam dengan kriteria ketuntasan minimal 79, siswa SMA Negeri 1 Mataram pada tahun pelajaran 2013-2014 yang memperoleh nilai diatas kriteria ketuntasan minimal mencapai $62 \%$.

Data diatas mencerminkan masih rendahnya prestasi belajar siswa dalam mata pelajaran kimia khususnya materi
Hidrolisis Garam, yang mana hal tersebut dapat terjadi karena beberapa faktor seperti pola pembelajaran yang masih berpusat teacher centered, sistem penilaian yang hanya berorientasi pada nilai produk sehingga hal ini berdampak pada diri siswa adanya kecendrungan bersikap kurang kreatif dalam mengikuti proses pembelajaran.

Dari hasi observasi terhadap beberapa guru kimia di SMA Negeri Mataram bahwa sistem pelajaran yang berlangsung masih dominan bersifat teacher centered. Keadaan ini menyebabkan siswa cendrung pasif dan kurang aktif. Perlu disadari bahwa berhasil tidaknya pencapaian tujuan pendidikan dipengaruhi oleh keberhasilan proses belajar mengajar.

Hasil observasi dilapangan yang diarahkan pada perangkat pembelajaran untuk mata pelajaran kimia menunjukkan bahwa $70 \%$ tujuan pembelajaran yang dirancang guru mengarah pada penguasaan produk sains dan hanya $30 \%$ yang mengarah pada keterampilan proses sains. Hasil ujian Praktek untuk materi Hidrolisis Garam pada tahun pelajaran 2013/2014 rata-rata nilai yang diperoleh siswa sebesar 71,75. Indikator yang dinilai dalam ujian praktek adalah cara menggunaan alat, bahan yang digunakan, menulis laporan yang memuat tujuan, alat dan bahan yang 
digunakan, prosedur kerja, hasil pengamatan,analisis data dan kesimpulan.

Berdasarkan pernyataan tersebut maka diperlukan suatu inovasi dalam pembelajaran berupa model pembelajaran yang interaktif dan dapat membantu siswa dalam penguasaan keterampilan proses sains. Salah satu inovasi pembelajaran tersebut dengan menggunakan model pembelajaran kooperatif. Sesuai dengan karakteristik pembelajaran kooperatif, siswa belajar dalam kelompok yang sifatnya heterogen. Pembelajaran kooperatif lebih mementingkan kerja sama siswa dalam kelompok untuk mencapai tujuan pembelajaran. Keberhasilan dari masing-masing anggota kelompok menunjang keberhasilan kekompok. Salah satu model pembelajaran kooperatif adalah model Investigasi Kelompok.

Menurut Depdiknas (2005), pada pembelajaran investigasi kelompok guru seyogyanya mengarahkan, membantu para siswa menemukan informasi, dan berperan sebagai salah satu sumber belajar yang mampu menciptakan lingkungan sosial yang dicirikan oleh lingkungan demokrasi dan proses ilmiah.

Menurut Winataputra (2001), model Group Investigation atau investigasi kelompok telah digunakan dalam berbagai situasi dan dalam berbagai bidang studi dan berbagai tingkat usia. Pada dasarnya model ini dirancang untuk membimbing para siswa mendefinisikan masalah, mengeksplorasi berbagai cakrawala mengenai masalah itu, mengumpulkan data yang relevan, mengembangkan dan mengetes hipotesis.

Penelitian tentang penerapan model Investigasi Kelompok dilakukan oleh Wiratana (2013) pada peserta didik SMP 1 Negara kelas VIII tahun pelajaran 2012/2013. Hasil penelitian menunjukkan bahwa (1) terdapat perbedaan keterampilan proses sains dan hasil belajar siswa antara siswa yang melaksanakan pembelajaran konvensional; (2) terdapat perbedaan keterampilan proses antara siswa yang belajar dengan model pembelajaran kooperatif tipe Investigasi Kelompok dengan siswa yang belajar secarakonvensional; (3) terdapat perbedaan hasil belajar sains siswa yang melaksanakan pembelajaran dengan model pembelajaran kooperatif tipe Investigasi Kelompok dengan siswa yang melaksanakan pembelajaran secara konvensional.

Terkait dengan Intelligence Quotient (IQ), Alfred Binet seorang tokoh utama perintis pengukuran inteligensi bersama Theodore Simon mendefinisikan inteligensi terdiri atas tiga komponen, yaitu ; (1) kemampuan untuk mengarahkan fikiran atau mengarahkan tindakan; (2) kemampuan untuk mengubah arah tindakan bila tindakan tersebut telah 
dilaksanakan dan (3) kemampuan untuk mengeritik diri sendiri atau melakukan autocriticism. (Azwar: 1996).

Penelitian tentang Intelligence Quotient (IQ) dilakukan oleh Bagus (2012) pada peserta didik SMA Negeri 1 Ubud. Hasil penelitian: (1) secara keseluruhan, hasil belajar Biologi siswa yang belajar dengan model pembelajaran problem based learning lebih tinggi daripada siswa yang belajar dengan model pembelajaran langsung, (2) untuk siswa yang memiliki IQ tinggi, hasil belajar Biologi siswa yang belajar dengan model pembelajaran problem based learning lebih tinggi daripada siswa yang belajar dengan model pembelajaran langsung, (3) untuk siswa yang memiliki IQ rendah, hasil belajar Biologi siswa yang belajar dengan model pembelajaran langsung lebih tinggi daripada siswa yang belajar dengan model pembelajaran problem based learning, dan (4) terdapat pengaruh interaksi antara model pembelajaran dengan IQterhadap hasil belajar Biologi siswa.

Keterampilan merupakan kemampuan menggunakan pikiran, nalar, dan perbuatan secara efisien dan efektif untuk mencapai suatu hasil tertentu, termasuk kreativitas. Proses didefinisikan sebagai perangkat keterampilan kompleks yang digunakan ilmuwan dalam melakukan penelitian ilmiah. Proses merupakan konsep besar yang dapat diuraikan menjadi komponen-komponen yang harus dikuasai seseorang bila akan melakukan penelitian.

Menurut Rustaman (2003), keterampilan proses adalah keterampilan yang melibatkan keterampilanketerampilan kognitif atau intelektual, manual dan sosial. Keterampilan kognitif terlibat karena dengan melakukan keterampilan proses siswa menggunakan pikirannya. Keterampilan manual jelas terlibat dalam keterampilan proses karena mereka melibatkan penggunaan alat dan bahan, pengukuran, penyusunan atau perakitan alat. Keterampilan sosial juga terlibat dalam keterampilan proses karena mereka berinteraksi dengan sesamanya dalam melaksanakan kegiatan belajarmengajar, misalnya mendiskusikan hasil pengamatan. Keterampilan proses perlu dikembangkan melalui pengalamanpengalaman langsung sebagai pengalaman belajar. Melalui pengalaman langsung, seseorang dapat labih menghayati proses atau kegiatan yang sedang dilakukan.

Menurut Rezba (2002) dalam Muhfahroyin (2007), keterampilan proses sains adalah keterampilan mengembangkan perolehan dalam proses pembelajaran oleh siswa. Siswa mampu menemukan dan mengembangkan sendiri fakta dan konsep serta menumbuhkan sikap dan nilai yang dimiliki. Keterampilan proses sains ini menjadi roda 
penggerak penemuan, pengembangan fakta, dan konsep.

Penelitian lain dilakukan oleh Darmayanti (2013) peserta didik kelas X semester 2 di SMA Negeri 1 Gianyar tahun pelajaran 2012/2013. Hasil penelitian menunjukkan (1) terdapat perbedaan keterampilan proses sains dan pemahaman konsep fisika antara kelompok siswa yang belajar dengan MCTL dan MPK; (2) terdapat perbedaan keterampilan proses sains dan pemahaman konsep fisika antara siswa yang memiliki gaya kognitif FI dan gaya kognitif FD; (3) terdapat interaksi antara model pembelajaran dan gaya kognitif terhadap keterampilan proses sains dan pemahaman konsep fisika siswa. Implikasi dari penelitian ini adalah perlunya pemilahan siswa yang akan mengikuti pembelajaran berdasarkan gaya kognitif yang dimiliki.

Berdasarkan pemaparan diatas maka tujuan dari penelitian ini adalah untuk mengetahui pengaruh model pembelajaran investigasi kelompok untuk meningkatkan keterampilan proses sains ditinjau dari Intelligence Quotient ( IQ ) siswa kelas XI SMA Negeri 1 Mataram.

\section{METODE}

Penelitian ini merupakan penelitian eksperimen. Populasi dalam penelitian ini adalah seluruh siswa kelas XI SMA Negeri 1 Mataram jurusan Sains sebayak 6 kelas dengan jumlah siswa seluruhnya 240 siswa. Sampel penelitian ini adalah kelas XI di SMA Negeri 1 Mataram sebayak dua kelas disemester genap tahun pelajaran 2014/2015. Satu kelas untuk eksperimen yaitu kelas XI Sains 6 dan satu kelas untuk kontrol yaitu kelas XI Sains 5. Pengambilan sampel dilakukan dengan cara melihat nilai rata-rata kimia pada semester 3 .

Proses pembelajaran dilakukan selama $12 \times 45$ menit. Pengumpulan data keterampilan proses dilakukan dengan Post-test yaitu tes keterampilan proses sains yang diberikan setelah berlangsungnya pembahasan mengenai materi Hidrolisis Garam. Tes keterampilan proses sains merupakan tes yang diberikan untuk mengetahui kemampuan siswa dalam keterampilan proses sains yang disesuaikan dengan tujuan pembelajaran dan indikator yang menandai ketercapaian tujuan pembelajaran. Tes dalam bentuk uraian (essay) untuk mengukur keterampilan proses sains sebanyak 9 butir soal. Soal-soal yang digunakan untuk mengukur 6 (enam) indikator keterampilan proses sains yang dikemukakan Subali (2009), yaitu: (1) mengamati; (2) mencatat/ merekam data informasi; (3) mengikuti perintah/ instruksi; (4) pengimplementasikan prosedur, teknik atau penggunaan peralatan;

menerapkan konsep. 


\section{HASIL DAN PEMBAHASAN}

Hasil post-test keterampilan proses sains yang dilakukan didapatkan data untuk siswa kelas eksperimen dan kelas kontrol seperti yang ditampilkan pada Tabel 1.

Tabel 1. Data Nilai Post-test Keterampilan Proses Sains.

\begin{tabular}{cccc}
\hline & & \multicolumn{2}{c}{ Nilai Post-test } \\
\cline { 3 - 4 } No & Aspek & $\begin{array}{c}\text { Kelas } \\
\text { Ivestigasi } \\
\text { Kelompok }\end{array}$ & $\begin{array}{c}\text { Kelas } \\
\text { konvension } \\
\text { al }\end{array}$ \\
\cline { 3 - 4 } 1 & $\begin{array}{l}\text { Jumlah } \\
\text { siswa }\end{array}$ & 40 & 40 \\
2 & $\begin{array}{l}\text { Nilai } \\
\text { tertinggi }\end{array}$ & 97 & 86 \\
3 & $\begin{array}{l}\text { Nilai } \\
\text { terendah }\end{array}$ & 46 & 44 \\
4 & $\begin{array}{l}\text { Nilai rata- } \\
\text { rata }\end{array}$ & 82,80 & 74,83 \\
\hline
\end{tabular}

Berdasarkan pada Tabel 1, rata-rata nilai post-test hasil belajar siswa kelas eskperimen dan kelas kontrol lebih tinggi kelas eksperimen dibandingkan dengan kelas kontrol. Hal ini semakin jelas terlihat pada grafik berikut:

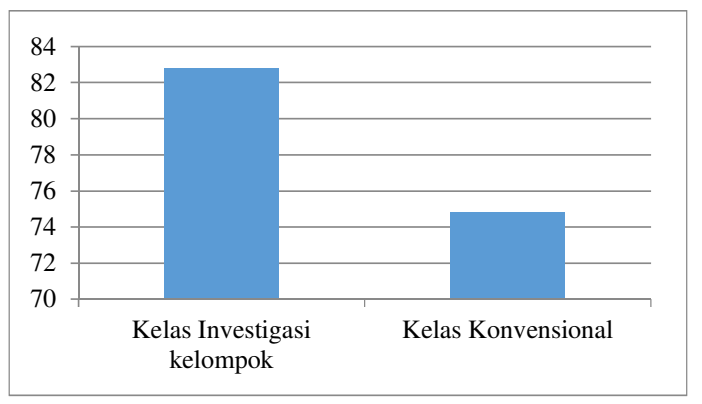

Gambar 1. Grafik Nilai Keterampilan Proses Sains Kelas Investigasi Kelompok dan Kelas Konvensional

Data nilai Intellegence Quotient (IQ) pada kelas eksperimen dan kontrol dapat dilihat pada tabel 2.

Tabel 2. Data Nilai Intellegence Quotient (IQ) Kelas Investigasi Kelompok dan Kelas Konvensional.

\begin{tabular}{cccc}
\hline \multirow{2}{*}{ No } & Aspek & \multicolumn{2}{c}{$\begin{array}{c}\text { Nilai Intellegence Quotient } \\
\text { IQ })\end{array}$} \\
\cline { 3 - 4 } & $\begin{array}{c}\text { Kelas } \\
\text { Ivestigasi } \\
\text { Kelompok }\end{array}$ & $\begin{array}{c}\text { Kelas } \\
\text { Konvensional }\end{array}$ \\
\hline 1 & $\begin{array}{l}\text { Jumlah } \\
\text { siswa }\end{array}$ & 40 & 40 \\
\hline 2 & $\begin{array}{l}\text { IQ } \\
\text { tertinggi }\end{array}$ & 119 & 119 \\
\hline 3 & $\begin{array}{l}\text { IQ } \\
\text { terendah }\end{array}$ & 103 & 104 \\
\hline 4 & $\begin{array}{l}\text { Rata-rata } \\
\text { IQ }\end{array}$ & 112 & 111 \\
\hline
\end{tabular}

Uji normalitas data dilakukan terhadap variabel terikat penelitian terdiri dari nilai keterampilan proses sains. Ringkasan hasil uji normalitas data penelitian dapat dilihat pada Tabel 3.

Tabel 3. Hasil Uji Normalitas Data dengan Uji One-Sample Kolmogorov-Smirnov Test Terhadap Variabel Terikat

\begin{tabular}{|c|c|c|c|c|c|c|c|}
\hline \multicolumn{8}{|c|}{ Tests of Normality } \\
\hline \multirow{2}{*}{\multicolumn{2}{|c|}{ KELAS }} & \multicolumn{3}{|c|}{ Kolmogorov-Smirnov $^{\mathrm{a}}$} & \multicolumn{3}{|c|}{ Shapiro-Wilk } \\
\hline & & Statistic & $\mathrm{df}$ & Sig. & Statistic & df & Sig. \\
\hline \multirow{2}{*}{ KPS } & Kontrol & .260 & 39 & .051 & .824 & 39 & .051 \\
\hline & Eksperimen & .157 & 40 & .065 & .905 & 40 & .053 \\
\hline
\end{tabular}


Dari hasil uji normalitas data yang ditunjukkan pada Tabel 2, diperoleh nilai signifikansi setiap variabel yang diuji lebih besar dari alpha 0,05 atau Sig. (p) > 0,05. Berarti data dari skor data keterampilan proses sains tidak menunjukkan penyimpangan dari distribusi normal, maka data keterampilan proses sains telah memenuhi persyaratan untuk dilakukan uji anacova.

Uji homogenitas dilakukan dengan uji Levene's Test of Equality of Error Variances. Hasil uji homogenitas data variabel terikat terdapat pada tabel 4.

Tabel 4. Hasil Uji Homogenitas Data Variabel Terikat

\begin{tabular}{|c|c|c|c|}
\hline F & df1 & df2 & Sig \\
\hline .357 & 1 & 77 & .552 \\
\hline
\end{tabular}

Dari Tabel 4 diketahui bahwa nilai signifikansi dari kelompok data yang diuji homogenitasnya sebesar 0,552. Nilai signifikansi tersebut ternyata lebih besar dari alpha 0,05 atau Sig. (p) $>0,05$. Dengan demikian dapat dikatakan bahwa data bersifat homogen.

Uji Hipotesis dilakukan dengan teknik statistik anacova tentang pengaruh perlakuan model terhadap variabel terikat penelitian yang disajikan pada tabel 5 .

Tabel 5. Hasil Tes Anacova pada Keterampilan proses sains

\begin{tabular}{lcrrrr}
\hline \multicolumn{1}{c}{ Source } & $\begin{array}{c}\text { Type III Sum of } \\
\text { Squares }\end{array}$ & df & Mean Square & \multicolumn{1}{c}{ F } & \multicolumn{1}{c}{ Sig. } \\
\hline Corrected Model & $1608.193^{\mathrm{a}}$ & 2 & 804.096 & 11.986 & .000 \\
\hline Intercept & 49.764 & 1 & 49.764 & .742 & .392 \\
\hline IQ & 1008.772 & 1 & 1008.772 & 15.037 & .000 \\
\hline kelas & 508.313 & 1 & 508.313 & 7.577 & .007 \\
\hline Error & 5098.523 & 76 & 67.086 & & \\
\hline Total & 499962.654 & 79 & & & \\
\hline Corrected Total & 6706.715 & 78 & & & \\
\hline
\end{tabular}

Nilai Signifikan yang diperoleh berdasarkan Tabel 5, adalah 0,007. Harga signifikan tersebut lebih kecil dari 0,05 $((\mathrm{p}<0,05))$ sehingga dapat disimpulkan penerapan pembelajaran investigasi kelompok berprngaruh terhadap keterampilan proses.

Berdasarkan hasil analisis data nilai Intellegence Quatient (IQ) kelas eksperimen memiliki nilai rata-rata Intellegence Quatient (IQ) tidak terlalu jauh berbeda dengan Intellegence Quatient (IQ) kelas kontrol. Sedangkan rata-rata nilai Post-test kelas eksperimen lebih tinggi dibanding dengan kelas kontrol. Kelas eksperimen memiliki nilai rata-rata Intellegence Quatient (IQ) sebesar 112 dan kelas kontrol memperoleh nilai rata-rata 
sebesar 111. Sedangkan untuk nilai Posttest kelas eksperimen memperoleh nilai 82,80 dan kelas kontrol memperoleh nilai 74,83. Jika dilihat dari perolehan nilai Post-test kedua kelas maka kelas eksperimen mempunyai nilai lebih tinggi dari pada nilai kelas kontrol

Hasil Post-test untuk indikator mengamati, nilai rata-rata pada kelas eksperimen sebesar 4,8 sedangkan nilai rata-rata untuk kelas kontrol sebesar 3,5. Nilai untuk kelas eksperimen lebih besar dari pada kelas kontrol. Hal ini disebabkan karena pada kelas eksperimen peserta didik sebelum melakukan pengamatan merencanakan terlebih dahulu apa yang akan diamati dengan melihat sumber dari buku dan internet dalam melakukan pengamatan menngunakan indera yang tepat. Pada kelas kontrol dalam melakukan pengamatan sesuai dengan apa yang ada di LKS dan hasil dicatat sesuai dengan tabel pengamatan yang disiapkan dalam LKS tanpa melihat sumber-sumber.

Skor nilai rata-rata untuk keterampilan mencatat dan merekam data informasi yaitu meerekam informasi sederhana dengan mempresentasikannya dalam bentuk grafik. Untuk kelas eksperimen memiliki nilai rata-rata sebesar 3,30 lebih besar dari kelas kontrol 2,85. Hal ini disebabkan karena pada kelas eksperimen dalam melakukan kegiatan praktikum yang berpedoman pada panduan investigasi kelompok yaitu berisi soal-soal membuat grafik titrasi asam basa peserta didik membuat sendiri grafik sesuai dengan hasil percobaan yang diperoleh. Sehingga dapat melatih peserta didik untuk merekam dan mengimplementasikan informasi yang diperoleh dalam berbagai macam bentuk

Nilai rata-rata keterampilan mengikuti perintah atau instruksi kelas eksperimen sebesar 4 lebih besar dari kelas kontrol sebesar 3. Indikator mengikuti perintah dalam hal ini mencari prosedur kerja dalam percobaan dalam kelas eksperimen mengikuti apa yang sudah direncanakan dalam kelompok dan setiap tahapan-tahapan sudah benar-benar dipahami, sehingga mempermudahkan peserta didik dalam mengikuti perintah atau instruksi. Pada kelas kontrol perintah atau instruksi sudah diberikan dalam LKS peserta didik tinggal mengikuti apa yang sudah tercantum dalam LKS tersebut sehingga ingatan siswa dan pemahaman tentang prosedur kerja diabaikan.

Nilai rata-rata keterampilan mengimplementasikan prosedur teknik, atau penggunaan peralatan kelompok eksperimen 4,75 lebih besar dari pada kelas kontrol 3,30. Pada kelas eksperimen dalam melakukan investigasi tentang alatalat dan bahan praktikum yang digunakan dalam percobaan hidrolisis garam peserta didik menggunakan alat-alat sederhana 
dan sudah dikenal fungsi masing-masing alat tersebut sehingga dalam menerapkannya lebih mudah. Sedangkan dalam kelas kontrol alat dan bahan yang digunakan sudah di siapkan sesuai dengan yang tercantum dalam LKS, sehingga keinginan peserta didik untuk mengetahui fungsi dari masing-masing alat yang digunakan tidak diperhatikan hanya mengikuti apa yang tercantum dalam LKS.

Nilai rata-rata untuk keterampilan menerapkan konsep kelas eksperimen sebesar 7,6 dan kelas kontrol sebesar 7,05. Nilai rata-rata kelas eksperimen lebih besar disebabkan karena pada kelas eksperimen dalam mengerjakan latihan soal-soal akademik yang menuntut peserta didik untuk memahami konsep dari apa yang dipelajari. Sehingga peserta diik tidak hanya mahir dalam melaksanakkan percobaan tetapi juga memahami konsep yang terkandung didalamnya. Penetahuan yang dimiliki peserta didik akan saling berhubungan dengan keterampilannya dalam melaksanakan prosedur praktikum dan menggunakan alat-alat laboratorium

$$
\text { Hasil observasi proses }
$$
pembelajaran dalam kelas Investigasi Kelompok peserta didik yang aktif dalam proses pembelajaran akan merasa senang karena peserta didik diberikan kesempatan untuk mencari materi yang sebanyakbanyaknya dari sumber-sumber pembelajaran, peserta didik banyak bertanya tentang materi-materi yang ditemukan sehingga pengetahuan yang diperoleh lebih luas

\begin{tabular}{|c|c|c|}
\hline Hasil & analisis & Anacova \\
\hline membuktikan & bahwa & perbedac \\
\hline
\end{tabular}
berpengaruh terhadap keterampilan proses sains. Hal ini didukung oleh penelitian yang dilakukan oleh Putera ( 2012 ) bahwa siswa yang memiliki Intellegence Quatient (IQ) tinggi, hasil belajar Biologi siswa yang belajar dengan model pembelajaran Problem Based Learning lebih tinggi dari pada siswa yang memiliki Intellegence Quatient (IQ) rendah. Penelitian lain yang dilakukan oleh Wibowo (2013) Intellegence Quatient (IQ) tinggi akan meningkatkan prestasi belajar

\section{KESIMPULAN}

Berdasarkan tujuan penelitian, deskripsi data, hasil analisis data dan pembahasan hasil penelitian, dapat diambil kesimpulan sebagai berikut: penerapan pembelajaran investigasi kelompok dapat meningkatkan keterampilan proses sains ditinjau dari Intellegence Quatient (IQ) siswa kelas XI SMAN 1 Mataram.

\section{DAFTAR PUSTAKA}

Ambarsari, W. Santosa, S. dan Maridi. 2013. Penerapan Pembelajaran Inkuiri Terbimbing Terhadap Keterampilan Proses Sains Dasar 
pada pelajaran biologi siswa kelas VIII SMP Negeri 7 Surakarta. Solo: Jurnal pendidikan Biologi. Vol.5 No.1 (81-95).

Anonim. 2011. Pembelajaran Sains Menurut Kurikulum 2006, Pendidikan dan Latihan Profesi Guru (PLPG) Penyelenggara Sertifikasi Guru Rayon 24. Makassar: Universitas Negeri Makassar

Bagus, Nym .2012. Implementasi Problem Based learning ( PBL) Terhadap hasil Belajar Biologi Ditinjau Dari Intelligence Quotient ( IQ). Tesis S2, Universitas Pendidikan Ganesha Singaraja.

Darmayanti N.W.S.Sadia,W.Sudiatmika, A.A.I.A.R. 2013. Pengaruh Model Collaborative Teamwork Learning terhadap Keterampilan Proses Sains dan Pemahaman Konsep Ditinjau dari Gaya Kognitif.e-journal Pasca Sarjana Universitas Pendidikan Ganesa Program Studi Pendidikan sains.Vol.3 : 1-12

Depdiknas. 2005. Panduan Pembelajaran Kooperatif Dengan Metode Investigasi Kelompok. Jakarta

Handari,R. Prayitno,B. Ariyanto,J. 2012. Penerapan Model Pembelajaran Kooperatif Group Investigation (GI) untuk Meningkatkan Keterampilan Proses Sains Siswa Kelas X5 SMAN 6 Surakarta Tahun Pelajaran 2011/2012. Pendidikan Biologi. Vol.4 No.1 : 106-116

Resti, A.M sigit P. \& Ersanghono K. 2010. Analisis kesulitan belajar kimia siswa SMA dalam memahami materi larutan penyangga dengan menggunakan Two-Tier Multiple Choice diagnostic instrumen. Jurnal Inovasi Pendidikan Kimia. Vol.4 No.1 (512-520).

Rustaman.N.Y. 2003. Strategi Belajar Mengajar Biologi. Jurusan Pendidikan Biologi.FPMIPA.UPI.

Saputri, C. A., Masykuri, Ashadi, dan Haryono. 2013. Pembelajaran Kimia Berbasis Masalah Dengan Metode Proyek Eksperimen Ditinjau Dari Kreativitas dan Keterampilan Menggunakan Alat Laboratorium. Jurnal Inkuiri. ISSN: 2252-7893, Vol 2, No. 3.

Subali, B. 2009. Pengembangan Tes Pengukuran Keterampilan Proses Sains Pola Divergen Mata Pelajaran Biologi SMA. Yogyakarta : Prosiding Seminar Nasional Biologi, Lingkungan dan Pembelajarannya. Jurdik Biologi, FPMIPA, Universitas Negeri Yogyakarta, 4 Juli 2009.

Sugiyono. 2010. StatistikUntuk Penelitian. Bandung : Alfabeta.

Wibowo, Murti dan Suriyasa. 2013.Pengaruh Problem Based Learning, Motivasi Belajar dan Intelligence Quotient Terhadap Prestasi Belajar Mata Kuliah Fisiologi Olah Raga Pada Mahasiswa Fakultas Olah Raga dan Kesehatan Universitas Pendidikan Ganesha.Jurnal Magister Kedokteran Keluarga. Vol 1 No 1: 49-60 
$\begin{array}{ccc}\text { Winataputra. 2001. Belajar Dan } & \text { Pembelajaran. } \\ \text { Depdiknas } & & \end{array}$

Wiratana, Sadia, dan Suma. 2013. Pengaruh Model Pembelajaran Kooperatif Tipe Investigasi Kelompok (Group Investigation) Terhadap Keterampilan Proses dan Hasil belajar Sains Siswa SMP.e-Journal Program Pascasarjana Universitas pendidikan Ganesa Program Studi IPA. Vol.3: 1-12.

Zulaeha. Wayan.dan Werdhiana,Komang. 2014. Pengaruh Model Pembelajaran Predict,Observe And Explain Terhadap Keterampilan Proses Sains Siswa Kelas X SMA Negeri 1 Balaesang.Jurnal Pendidikan Fisika Tadulako.Vol.2 No : 1-8. 